\title{
Photoresponsive Azobenzene-modified Gold Nanoparticle
}

\author{
Kyong-ha Shin and Eun Ju Shin* \\ Department of Chemistry, Sunchon National Chiversit, Suncheon. Jeonnam 540-742, Korea. "E-mail: ejsólsunchon ackr \\ Received March 25, 2008
}

Key Words : Azobenzene, Isomerization, Au nanoparticle, Organic-inorganic nanolỵbrid, Absorption spectra

Recently, inorganic nanoparticles have attracted great attention because nanoparticles exhibit interesting sizedependent physical and chemical properties due to intermediate size between single molecules and bulk materials. ${ }^{1-5}$ Especially. the design and preparation of functional nanomaterials obtained from tunable and controlled nanoparticle self-assembly becomes one of most exciting research subject due to many practical applications using their remarkable optical catalytical electronic. biological. and magnetic properties. based on high surface-to-volume ratios and small size effect. Organized organic-inorganic nanohybrids can be constructed by assembling monolayers of organic molecules containing functional groups such as thiols on the threedimensional surface of metal nanoparticles. ${ }^{6-\delta}$ The hybrid nanomaterials consisting of inorganic nanoparticle and photoactive organic molecules may provided light-controlled nano-devices.-13 Incorporation of photo-switched organic molecule into inorganic nanoparticle is one of good strategies for realization of molecular device. Photo-induced trans-cis isomerization of organic photochromes such as diarylethenes $^{1+16}$ and azobenzene ${ }^{17.18}$ could lead to the modulation of hỵbrid nanomaterials by external optical stimulation. In this study, we describe the preparation and photoisomerization behavior of gold nanoparticle modified with photoresponsive azobenezene-alkanethiol. This photoresponsive Au nanoparticle stabilized by self-assembled layer of azobenezene-alkanethiol may function as lightcontrolled nano-switch.
Azobenzene-capped gold nanoparticle was prepared as shown in Figure 1 and the detailed procedure was described in Experimental Section. FT-IR spectra show the disappearance of S-H stretching band at $2550 \mathrm{~cm}^{-1}$ in the azobenzene-alkanethiol stabilized gold nanoparticle. Transmission electron microscopic (TEM) image in Figure 2 showed the fomation of azobenzene-alkanethiol functionalized gold nanoparticle of diameter in the range 2-3 nm. There are 45 azobenzene-alkanethiols on the gold surface, estimated from elemental analysis data ( $\mathrm{Au} 78.1 \%$ (by difference): $\mathrm{C} 15.2 \%$ : H 1.6\%: N 1.9\%: S 2.1\%) and average number of $269 \mathrm{Au}$ atoms per core of $2 \mathrm{~nm}$ dianeter. ${ }^{19}$

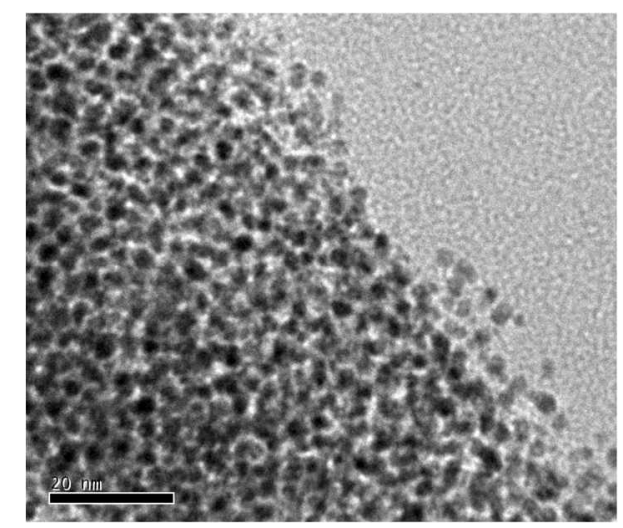

Figure 2. Transmission electron microscopic (TEM) image of azobenzene-alkanethiol functionalized gold nanoparticle.
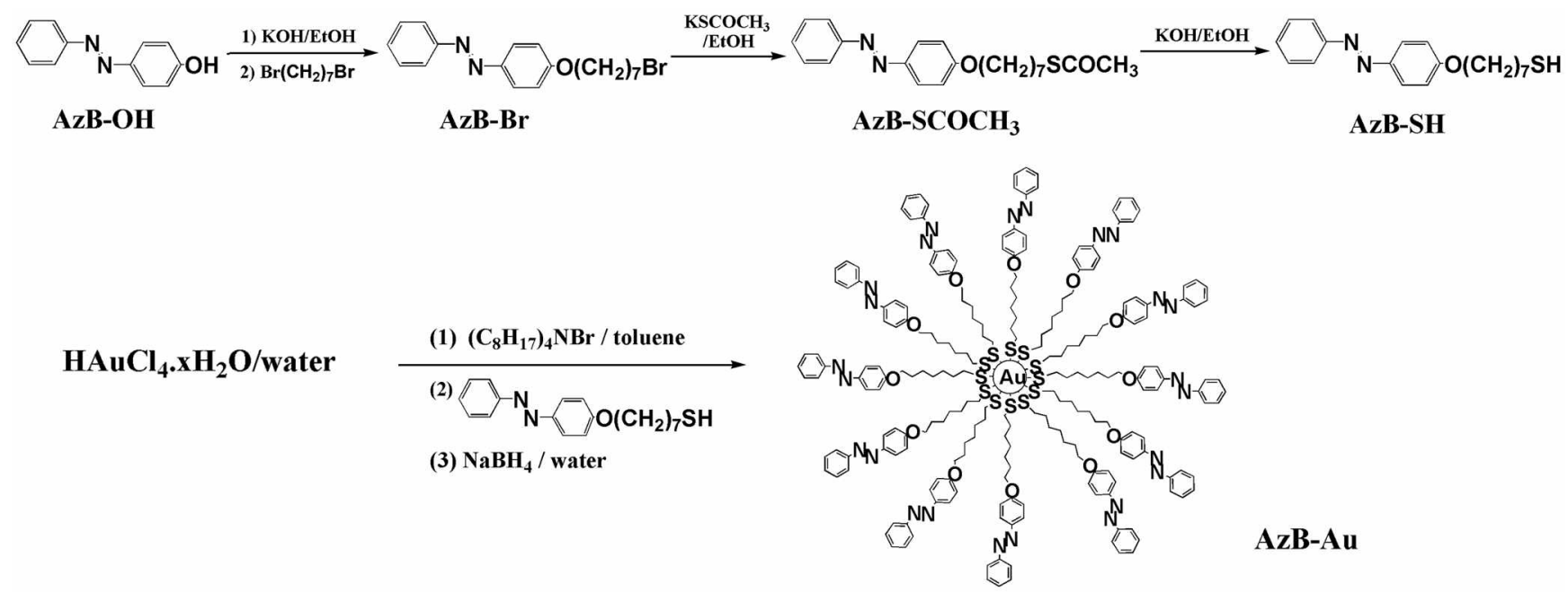

AzB-Au

Figure 1. Preparation of azobenzene-alkanethiol functionalized gold nanoparticle. 


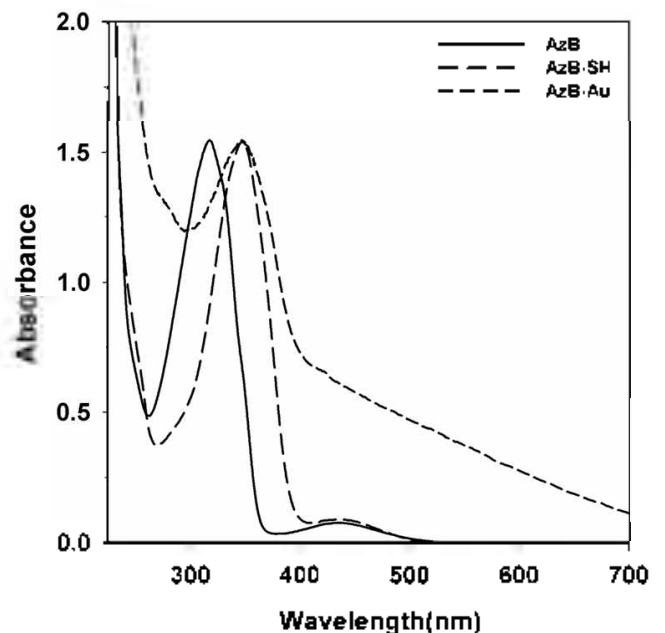

Figure 3. Absorption spectra of azobenzene-alkanethiol functionalized gold nanoparticle (AzB-Au), $\mathrm{PhN}=\mathrm{NPh}-\mathrm{O}\left(\mathrm{CH}_{2}\right)$ ? $\mathrm{SH}(\mathrm{AzB}-$ $\mathrm{SH}$, and azobenzene $(\mathrm{AzB})$ in dichloromethane.

The absorption spectra of azobenzene-capped gold nanoparticle in dichloromethane are shown in Figure 3 and absorption maximum appears at $347 \mathrm{~nm}$, due to $\pi-\pi^{*}$ absorption of azobenzene moiety. which is red-shifted compared with absorption band $(318 \mathrm{~nm})$ of azobenzene and
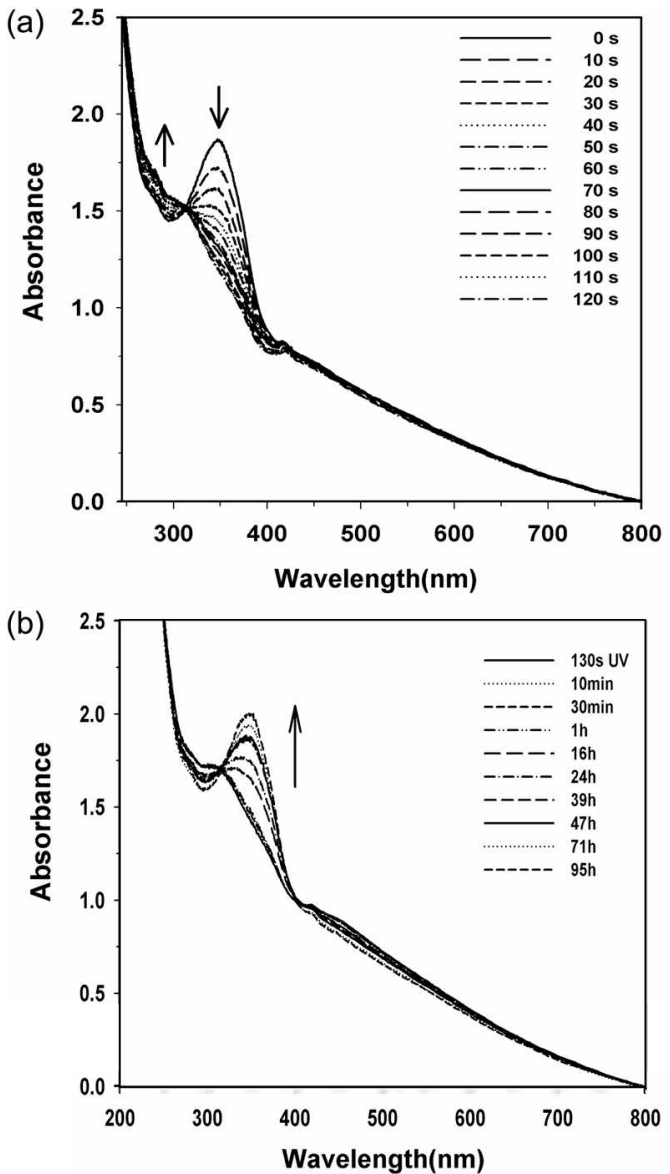

Figure 4. Absorption spectral changes of azobenzene-alkanethiol functionalized gold nanoparticle in dichloromethane (a) with irradiation tine (0)-120 s, $10 \mathrm{~s}$ interval) on irradiation at $350 \mathrm{~mm}$ and (b) with incubation time in the dark after $130 \mathrm{~s}$ irradiation at $350 \mathrm{~nm}$. similar to that $(347 \mathrm{~mm})$ of AzB-SH. $\mathrm{n}-\pi^{*}$ absorption of azobenzene moiety observed in absorption spectra of both azobenzene ( $434 \mathrm{~nm}$ ) and AzB-SH (434 num) is not observed to be obscured by bonding of azobenzene alkanethiol on $\mathrm{Au}$ surface.

Azobenzene anchored on gold nanoparticle accomplishes trans $\rightarrow$ cis photoisomerization upon ultraviolet irradiation and monitored by absorption spectral changes. Photogenerated $c i s$-isomer reverts to trans-isomer when the irradiated solution is stored in the dark. In dilute solution. thermal back isomerization follows first-order kinetics. Photoirradiation was carried out in a Rayonet RPR 100 photochemical reactor equipped with 4 Southern Ultraviolet $3500 \AA$ lamps using pyrex reaction tube in dichloromethane solution. The absorption spectral changes of azobenzene-alkanethiol functionalized gold nanoparticle in dichloromethane during 120 sec by $10 \mathrm{sec}$ interval on irradiation at $350 \mathrm{~nm}$ were measured for monitoring the photoisomerization of azobenzene (Figure 4a). On $350 \mathrm{~nm}$ irradiation, absorption band at 347 $\mathrm{nm}$ decreases and absorption band at $434 \mathrm{~nm}$ increases, as
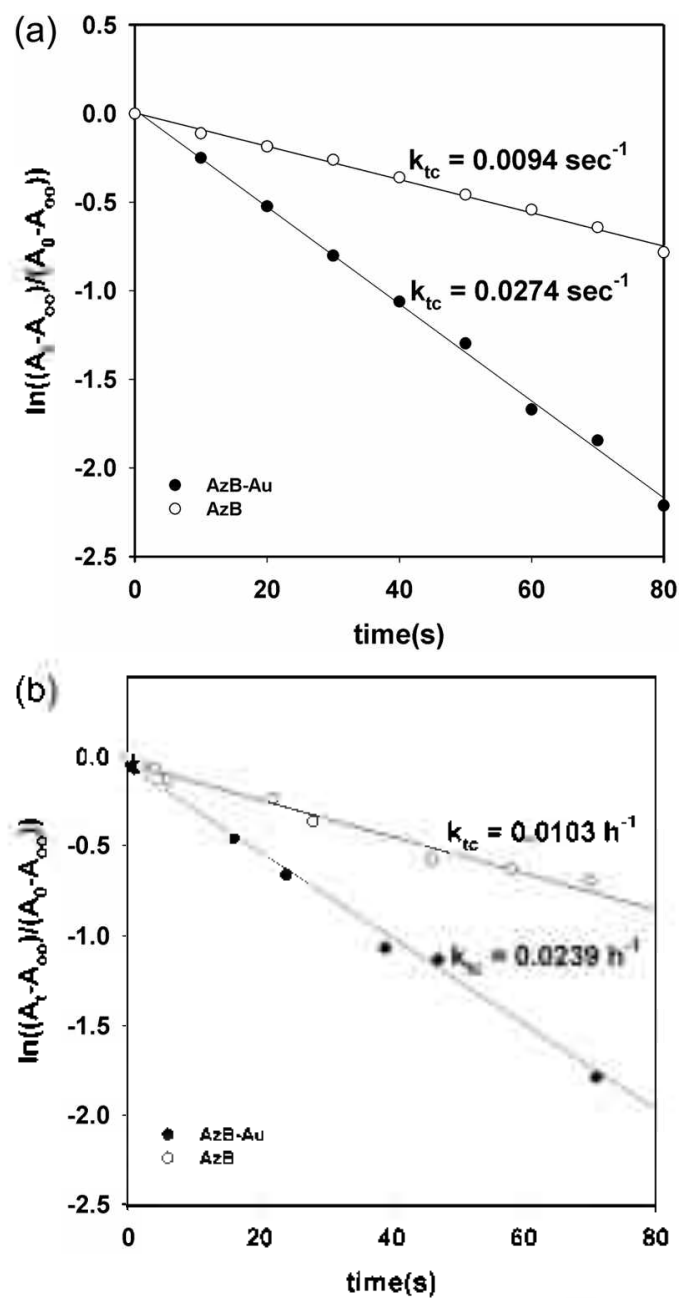

Figure 5 . Plots of time versus $\ln \left(\left(A_{1}-A_{x}\right)\left(A_{3}-A_{0}\right)\right.$ ) for obtaining (a) the initial reaction rates $k_{t \rightarrow c}$ of trans $\rightarrow$ cis photochemical isomerization and (b) the initial reaction rates $k_{c \rightarrow t}$ of cis $\rightarrow$ trans thermal isomerization of azobenzene-alkanethiol functionalized gold nanoparticle AzB-Au and azobenzene AzB. 
azobenzene moiety of azobenzene-alkanethiol functionalized gold nanoparticle converts photochemically from trans form to $c i s$ form. Sinilar to simple azobenzene molecule, azobenzene modified gold nanoparticle carried out very fast $t r m s \rightarrow c i s$ photoisomerization on irradiation of $350 \mathrm{~nm}$ light. completed within $120 \mathrm{sec}$

Thernal reversion of azobenzene-alkanethiol functionalized gold nanoparticle is very slow at room temperature. Thermal back isomerization followed by absorption spectral changes in dichloronethane during incubation in the dark after irradiation at $350 \mathrm{mon}$ for $130 \mathrm{sec}$ is shown in Figure 4b. As the irradiated solution in dichloromethane were kept in the dark. very slow reversion from cis form to troms form occur and is conteleted after 5 days through thennal isomerization.

Trans $\rightarrow$ cis photoisomerization rates $k_{s c}$ are calculated from the absorbance changes with irradiation time $t$ using the following equation.

$$
\ln \frac{A_{\infty}-A_{t}}{A_{\mathrm{co}}-A_{\mathrm{i}}}=-k_{t \rightarrow c} t
$$

where $A_{i ! .} A_{i}$ and $A_{\infty}$ represent absorbances before irradiation, at irradiation time $t$, and at the photostationary state gained after the prolonged irradiation, respectively.

The initial reaction rates $k_{t \rightarrow c}$ of $t r c m s \rightarrow c i s$ photochemical isomerization obtained from the plot (see Figure 5a) using equation 1 are higher for azobenzene-alkanethiol functionalized gold nanoparticle $\left(0.027 \mathrm{~s}^{-1}\right)$ than for azobenzene $\left(0.009 \mathrm{~s}^{-1}\right)$.

Applying the same equation. the initial reaction rates $k_{c \rightarrow t}$ of cis $\rightarrow$ trans thennal isomerization can also be estimated (see Figure 5b). Thermal reversion rate reverted to the original dark-incubated spectrum of trans-isomer molecule over 6 days in the dark is higher for azobenzene-alkanethiol functionalized gold nanoparticle $\left(0.024 \mathrm{~h}^{-1}\right)$ than for simple azobenzene $\left(0.010 \mathrm{~h}^{-1}\right)$.

Both trans $\rightarrow$ cis photochenical isomerization rate and cis $\rightarrow$ trons thermal isomerization rate become accelerate when azobenzene is anchored on metal surface. The understanding for this acceleration of isomerization in azobenzene-alkanethiol functionalized gold nanoparticle needs further work.

In summary. gold nanoparticle modified with photoresponsive azobenezene-alkanethiol molecules has been prepared and its photoisomerization behavior has been studied. Azobenzene-modified gold nanoparticle carried out very efficient trans $\rightarrow$ cis photoisomerization on irradiation of $350 \mathrm{~mm}$ light similar to azobenzene and reached to the photostationary state within $180 \mathrm{~s}$. After the dark incubation. slow thermal back reversion to trans form is completed within 5 dayss. Both trans $\rightarrow$ cis photochemical isomerization rate and cistrons thermal isomerization rate become faster when azobenzene is anchored on metal surface.

\section{Experimental Section}

Synthesis. The synthetic procedure of azobenzene- alkanethiol functionalized gold nanoparticle is shown in Figure 1. Williamson ether synthesis reaction of 4-hydrosyazobenzene and 1,7-dibromoheptane. thioesterification with potassium thioacetate, and subsequent base deprotection afforded $\mathrm{PhN}=\mathrm{NPh}-\mathrm{O}\left(\mathrm{CH}_{2}\right)_{7} \mathrm{SH}$

Synthesis of $P h N=N P h-O\left(C H_{3}\right)-B r(A z B-B r)$ : To a solution of 4-hydroxyazobenzene (AzB-OH, $1.0 \mathrm{~g} .5 \mathrm{mmol}$ ) in deosygenated $\mathrm{EtOH}(50 \mathrm{~mL})$ was added a solution of $\mathrm{KOH}$ (10 mL. $0.5 \mathrm{M}, 5 \mathrm{mmol}$ ) in deosygenated EtOH. After refluxing the mixture for $30 \mathrm{~min}$, a solution of 1.7-dibromoheptane $(0.86 \mathrm{~mL}, 5 \mathrm{mmol})$ in deosygenate $4 \mathrm{~d} \mathrm{EtOH}(20$ $\mathrm{mL}$ ) was added dropwise for $30 \mathrm{~min}$ to the reaction mixture and the resulting solution was refluxed for an additional 5 hours. As the solution cooled. it became cloudy with a $\mathrm{KBr}$ precipitate. The reaction mixture was concentrated and extracted with benzene and diethyl ether. The combined organic extract was washed with water. dried over magnesium sulfate and filtered. The solvent was evaporated. The crude mixture was purified with silica gel columu chromatography eluted with a 1:9 ether/hexane. Al orange crystalline solid was isolated $(0.65 \mathrm{~g}$. yield $35 \%)$. ${ }^{1} \mathrm{H}$ NMR $(400 \mathrm{MHz}$, $\left.\mathrm{CDCl}_{3}\right) \delta 1.28-1.43$ (m. $\left.6 \mathrm{H},-\mathrm{OCH}_{2} \mathrm{CH}_{2}\left(\mathrm{CH}_{2}\right)_{3} \mathrm{CH}_{2} \mathrm{CH}_{2}-\mathrm{Br}\right)$, 1.74-1.83 (m, $\left.4 \mathrm{H} . \quad-\mathrm{OCH}_{2} \mathrm{CH}_{2}\left(\mathrm{CH}_{2}\right)_{3} \mathrm{CH}_{2} \mathrm{CH}_{2}-\mathrm{Br}\right) .3 .36(\mathrm{t}$, $\left.2 \mathrm{H} . J=6.4 \mathrm{~Hz} .-\mathrm{O}\left(\mathrm{CH}_{2}\right)_{6} \mathrm{CH}_{2}-\mathrm{Br}\right), 3.98(\mathrm{t}, 2 \mathrm{H}, J=6.4 \mathrm{~Hz}$, $\left.-\mathrm{OCH}_{2}\left(\mathrm{CH}_{2}\right)_{6}-\mathrm{Br}\right), 6.93$ (d. $2 \mathrm{H} . J=8.9 \mathrm{~Hz}$. phenyl). 7.31 (d. IH. $J=7.1 \mathrm{~Hz}$. phenyl), 7.43 (t. $2 \mathrm{H}, J=7.2,7.7 \mathrm{~Hz}$. phenyl), 7.80 (d, $2 \mathrm{H}, J=7.4 \mathrm{~Hz}$. phenyl), 7.83 (d. $2 \mathrm{H} . J=8.9 \mathrm{~Hz}$, phenyl) ppm. MS $m \geq 374\left(\mathrm{M}^{+}\right)$.

Synthesis of $\mathrm{PhN}=\mathrm{NPh}-\mathrm{O}\left(\mathrm{CH}_{2}\right)_{-} \mathrm{SCOCH} \mathrm{CH}_{3}(\mathrm{AzB}-\mathrm{SCOCH})$ : To a solution of $\mathrm{PhN}=\mathrm{NPh}-\mathrm{O}\left(\mathrm{CH}_{2}\right)_{7} \mathrm{Br}(\mathrm{AzB}-\mathrm{Br}, 0.38 \mathrm{~g} . \mathrm{l}$ mmol) in deosygenated $\mathrm{EtOH}(50 \mathrm{~mL})$ was added potassium thioacetate $(0.12 \mathrm{~g}, 1.1 \mathrm{~mm}$ ol). After refluxing the mixture for $24 \mathrm{hr}$. the solvent was evaporated. The crude mixture was purified with silica gel column chromatography eluted with a 1:9 ether/hexane. An orange crystalline solid was isolated $\left(0.15 \mathrm{~g}\right.$. yield $41 \%$ ). ${ }^{1} \mathrm{H}$ NMR $(400 \mathrm{MHz}$, $\left.\mathrm{CDCl}_{3}\right) \delta 1.15-1.20\left(\mathrm{~m} .8 \mathrm{H} .-\mathrm{OCH}_{2} \mathrm{CH}_{2}\left(\mathrm{CH}_{2}\right)_{4} \mathrm{CH}_{2}-\mathrm{SCOCH}_{3}\right)$, 1.75 (q. $\left.2 \mathrm{H} .-\mathrm{OCH}_{2} \mathrm{CH}_{2}\left(\mathrm{CH}_{2}\right)_{4} \mathrm{CH}_{2}-\mathrm{SCOCH}_{3}\right) .2 .26(\mathrm{~s}, 3 \mathrm{H}$, $\left.-\mathrm{SCOC} \underline{\mathrm{H}}_{3}\right), 2.81$ (t. $\left.2 \mathrm{H} . J=7.3 \mathrm{~Hz}_{3}-\mathrm{O}\left(\mathrm{CH}_{2}\right)_{6} \mathrm{CH}_{2}-\mathrm{SCOCH}_{3}\right)$, 3.96 (t. $2 \mathrm{H}, J=6.5 \mathrm{~Hz},-\mathrm{OC} \underline{\mathrm{H}}_{2}$ ) .6 .93 (d, $2 \mathrm{H} . J=8.9 \mathrm{~Hz}$, phenyl). 7.37 (d. $1 \mathrm{H}, J=7.0 \mathrm{~Hz}$, phenyl). 7.43 (t. $2 \mathrm{H} . J=$ $7.0 .7 .4 \mathrm{~Hz}$, phenyl). 7.81 (d. $2 \mathrm{H} . J=7.2 \mathrm{~Hz}$. phenyl). 7.84 (d. $2 \mathrm{H}, J=8.9 \mathrm{~Hz}$, phenyl) ppm. $\mathrm{MS} m z 370\left(\mathrm{M}^{+}\right)$.

Synthesis of $P h N=N P h-O\left(C H_{2}\right)-S H(A z B-S H)$ : To a solution of $\mathrm{PhN}=\mathrm{NPh}-\mathrm{O}\left(\mathrm{CH}_{2}\right)_{7} \mathrm{SCOCH}_{3}\left(\mathrm{AzB}-\mathrm{SCOCH}_{3}, 0.11 \mathrm{~g}\right.$. $0.3 \mathrm{mmol}$ ) in deosygented $\mathrm{EtOH}(30 \mathrm{~mL})$ was added a solution of $\mathrm{KOH}(0.7 \mathrm{~mL} .0 .5 \mathrm{M} .0 .4 \mathrm{mmol})$ in deosy genated $\mathrm{EtOH}$. After stirring the mixture for $1 \mathrm{lor}$, a solution of $\mathrm{NH}_{4} \mathrm{Cl}(1.5 \mathrm{~mL}, 1.0 \mathrm{M}, 1.5 \mathrm{mmol})$ in deoxygenated water was added. The resulting solution was concentrated and extracted with diethyl ether. The ether solution was washed first with water and then with saturated aqueous $\mathrm{NaCl}$ solution, dried over magnesium sulfate and filtered. The solvent was evaporated. The crude mixture was purified with silica gel column chromatography eluted with a 1:9 ether/hexane. An orange solid was isolated $(0.04 \mathrm{~g}$. yield $41 \%$ ). ${ }^{1} \mathrm{H}$ NMR (400 MHz. $\left.\mathrm{CDCl}_{3}\right) \delta 1.41-1.61$ (m. 8H, 
$\left.-\mathrm{OCH}_{2} \mathrm{CH}_{2}\left(\mathrm{CH}_{2}\right)_{4} \mathrm{CH}_{2}-\mathrm{SH}\right), 1.76\left(\mathrm{q} .2 \mathrm{H}_{3}, J=7.4 \mathrm{~Hz},-\mathrm{OCH}_{2}-\right.$ $\mathrm{CH}_{2}-$ ). 2.47 (q. $\left.2 \mathrm{H} . J=7.3 \mathrm{~Hz},-\mathrm{O}\left(\mathrm{CH}_{2}\right)_{6} \mathrm{CH}_{2}-\mathrm{SH}\right) .3 .97$ (t. $2 \mathrm{H}, J=6.5 \mathrm{~Hz},-\mathrm{OCH}_{2}-6.93$ (q. $2 \mathrm{H}_{3} J=6.9 \mathrm{~Hz}$. phenyl). 7.38 (d. $1 \mathrm{H} . J=6.5 \mathrm{~Hz}$, phenyl). 7.43 (d, $2 \mathrm{H}, J=7.4 \mathrm{~Hz}$. phenyl), $7.8 \mathrm{l}$ (q. $2 \mathrm{H}, J=7.9 \mathrm{~Hz}$. phenyl). $7.83-7.85$ (q, $2 \mathrm{H} . J$ $=7.0 \mathrm{~Hz}$, phenyl) ppm. MS $m z 328\left(\mathrm{M}^{+}\right)$.

Preparation of azobenzene-capped gold nanoparticle $(A z B-A v i)$ : A solution of $\mathrm{HAuCl}_{4} \cdot 3 \mathrm{H}_{3} \mathrm{O}(0.53 \mathrm{~g}, 1.6 \mathrm{mmol})$ in water $(40 \mathrm{~mL})$ was mixed with a solution of tetraoctylanmonium bromide $(1.4+\mathrm{g} .2 .6 \mathrm{mmol})$ in toluene (140 $\mathrm{mL}$ ). The two-phase mixture was vigorously stirred until all the tetrachloroaurate was transferred into the organic layer and $\mathrm{PhN}=\mathrm{NPh}-\mathrm{O}\left(\mathrm{CH}_{2}\right)_{7} \mathrm{SH}$ (AzB-SH. $8.8 \mathrm{mg} .2 .7 \mathrm{mmol}$ ) was added to the organic layer. A freshly prepared solution of sodium borolydride $(2.8 \mathrm{~g} .75 \mathrm{mmol})$ in water $(140 \mathrm{~mL})$ was slowly added with vigorous stirring. After the further stirring for 3 hrs, the organic layer was separated and the solution was filtered and washed with acetonitrile. A dark brown solid was obtained $(0.16 \mathrm{~g})$.

Spectroscopic measurements. ${ }^{1} \mathrm{H}$ NMR spectra were measured on a $400 \mathrm{MHz}$ Bruker Avance 400 NMR spectrometer in chloroform- $d$. Mass spectra were obtained on Micromass (UK) Platform II GC/LC-Mass Spectrometer. IR spectra were measured on Midac Prospect FT-IR spectrometer. TEM image was obtained on JEM-2010 (JEOL, $200 \mathrm{kV}$ ) TEM. Elemental analysis was accomplished with Leco CHNS-932. Absorption spectra were recorded on a Shimadzu UV-2401PC spectrophotometer. Steady-state fluorescence spectra were recorded on a SLM-Aninco AB2 luminescence spectrophotometer. Photoirradiation was carried out in a Rayonet RPR 100 photochenical reactor equipped with Southen Ultraviolet $3500 \AA$ lamps using pyrex reaction tube in dichloromethane solution. Reaction progress of photoisomerization on UV irradiation and reverse thermal isomerization in the dark was monitored by change of absorption spectra.
Acknowledgements. This work was supported by the Korea Science and Engineering Foundation (KOSEF) grant funded by the Korea government (MOST) (No. R01-2006$000-10262-0)$

\section{References}

1. Thomas. K. G.: Kamat. P. V. Acc. Chem. Res. 2003. 36.888.

2. Kamat. P. V. Pure Appl. Chem 2002. 7t, 1693.

3. Shenhar. R.: Rotello. V. M. Acc. Chem. Res. 2003, 36. 549.

4. Shipway, A. N.: Katz. E.: Willner, I. ChemPhusChem 2000. 1. 18.

5. MeContell. W. P.: Novak. J. P.: Brousseau. L. C.. III: Fuierer. R. R.: Tenent. R. C.: Feldheim. D. L. J. Phrs Chem. B 2000. 10t. 8925.

6. Templeton, A. C; Wuelfing, W. P; Murray, R. W. Acc. Chem. Res. 2000, 33, 27.

7. Brust, M.: Fink. J.: Bethel1. D.; Schiffrin, D. J.; Kiely, C. J. Chem Soc. Chent Conmm 1995. 1655.

8. Sarathy. K. V: Kulkarni. G. U.: Rao. C. N. R. J. Chem. Soc., Chent Conmum. 1997. 537.

9. Thomas. K. G.; Ipe, B. I.: Sudeep, P. K. Pwr Appl. Chem 2002. 74. 1731.

10. Ipe. B. I.: Mashima, S.: Thomas, K. G. J. Am. Chem. Soc. 2003. 125.7174

11. Fukuzumi. S.: Endo. Y.: Kashiwagi. Y.: Araki. Y.: Ito. O.: Innahori. H. J. Phys. Chent. B 2003. 107. 11979

12. Hasobe. T.: Imahori, H.: Kamat. P. V: Aln. T. K.: Kim, S. K: Kim. D.: Fujimoto, A.: Hirakawa, T.: Fukuzumi, S. J. Am. Chem. Soc. $2005,127,1216$.

13. Medintz, I. L.: Trammell, S. A.: Mattoussi. H.; Mauro. J. M. d. Ant Chem. Soc. 2004. 126. 30.

14. Shin. E. J.: Tung. H.-S. J. Photochent Photobiol A: Chemistry 2005. 173.195.

15. Shin. E. J. Bull. Korean Chem. Soc, 2006, 27,751.

16. Shin. E. J. Bull. Korean Chem. Soc, 2006, 27, 1897.

17. Choi, D. O.; Lee, J.-h.; Shin, K.-h.: Shin, E. J. Bull Korean Chem. Soc. 2007. 28.983.

18. Park. J. E.: Shitr. E. T. Spectrochimica Acta Part A: Molecular and Bionolecular Spectroscopy 2007. 68.554.

19. Labande, A.; Astruc, D. J. Chem. Soc. Chem. Conmm. 2000. 1007 